\title{
Ritual Consecration in the Context of Writing the Holy Scrolls: Jews in Medieval Europe between Demarcation and Acculturation
}

\author{
Annett Martini
}

\begin{abstract}
The objective of this article is to outline a hitherto neglected aspect of writing holy scrolls for ritual use, which in medieval Europe became a crucial subject of discussion: the ritual consecration of certain processes during the manufacturing of STaM with a special emphasis on writable skins. Taking into account Jewish and Christian sources, many of which have not been scrutinized to date, a paradox that perfectly reflects the ambivalent relationship of Jews and Christians in the Middle Ages will be revealed. On the one hand, the ritual sanctification can be read as an act of demarcation by which Jews drew a clear line between holy and profane - and Jews and non-Jews. On the other hand, it becomes evident that there was not only an artisanal exchange but a mutual interaction in terms of ritual and performance as well.
\end{abstract}

\section{Keywords}

consecration - sanctification - STaM - holy scrolls - ritual writing

Looking at the material features of Torah scrolls and the small pieces of written parchment within mezuzot and tefillin (STaM), one immediately becomes aware of the serious endeavor of scribes to avoid any kind of modifications. The quality of the parchment, the color of the ink, the layout and the forms of letters at least since late antiquity have remained unchanged except for minimal variations. ${ }^{1}$ Apparently, the different cultural environments of the Jewish

1 Ludwig Blau, Studien zum althebräischen Buchwesen und zur biblischen Litteratur- und Textgeschichte (Strasburg: Karl J. Trübner, 1902), 9-37; Emanuel Tov, Scribal Practices and Approaches Reflected in the Texts Found in the Judean Desert (Leiden: Brill, 2004), 31-55; 
communities in the diaspora did not touch the world of a Sofer STaM who was entrusted with passing on the holy scrolls within very tight halachic boundaries. However, numerous responses by Geonim, halachic discussions on scribal rules from different times and places of the diaspora, and a considerable number of manuals for scribes or those who wanted to be a professional sofer show a different picture. Here we find not only reflections of internal Jewish tensions and philosophical trends or mystical movements, but also concessions with respect to media and the realities of technical progress, which often challenge the Jewish notion of authenticity regarding the holy scrolls.

In this article, I will confine myself to only one subject of the scribal literature: the ritual consecration of almost all parts of manufacturing the STaM, with a special emphasis on writable skins. It will be argued that the issue of kosher materials for writing STaM in medieval Europe was not so much characterized by the question of workmanship-which halachic treatises and responses from the Islamic region give evidence of ${ }^{2}$ - but by the concern for purity and sanctification.

The reason for this-and this is my hypothesis-lies in the ambivalent relationship between Jews and Christians especially in terms of three aspects I will discuss. First: the dependency of Western Jewry on Christian tanners. Second: the Christian conception of preparing, writing and illuminating holy books in the environment of monastic scriptorium. Third, it will be argued that the tremendous increase in consecrations and benedictions within Christian

Emanuel Tov, Der Text der Hebräischen Bibel. Handbuch der Textkritik (Stuttgart: Kohlhammer, 1997), 92-128 and 189-241; Menachem Haran, "Scribal Workmanship in Biblical Times: The Scrolls and the Writing Implements," Tarbiz 5o (1981): 65-87 [Hebrew]; Menachem Haran, "Book-Scrolls in Israel in Pre-Exilic Times," Journal of Jewish Studies 33 (1982): 161-173; John B. Poole and Ronald Reed, "The Preparation of Leather and Parchment by the Dead Sea Scrolls Community," Technology and Culture 3 (1962): 1-26; Michael L. Ryder, "Remains Derived from Skin," in Science and Archaeology, eds. Don R. Brothwell and Eric S. Higgs (London: Blackwell Scientific Publishers, 1970), 539-554; Yigael Yadin, "Tefillin (Phylacteries) from Qumran," Eretz-Israel 9 (1969): 60-83 [Hebrew]; Yehudah B. Cohn, Tangled up in Text. Tefillin and the Ancient World, Brown Judaic Studies 351 (Providence, RI: Brown University, 2008); Malachi Beit-Arié, Hebrew Codicology (Jerusalem: Israel Academy of Sciences and Humanities, 1981); Allan David Crown, "Studies in Samaritan Scribal Practices and Manuscript History: III. Columnar Writing and the Samaritan Massorah," Bulletin of the John Rylands University Library 67 (1984): 349-381; Johann Maier, Die Tempelrolle vom Toten Meer (Munich/Basel: Ernst Reinhardt, 1978).

2 Blau, Studien zum althebräischen Buchwesen, 26-29; Menahemem Haran, "Bible Scrolls in Eastern and Western Communities," Hebrew Union College Annual LVI (1985): 21-62 and $37-43$. 
religious life was a pivotal initiation for the new conception of sanctifying the scrolls for their holy purpose.

In order to explicate modifications and innovations of the medieval scribal law, I shall begin with an outline of the early rabbinic position regarding writing materials and the usage of the term 'ibbud lishmah, as here we find the point of departure for all further discussion. After presenting the rabbinic ideal I turn to medieval Europe and examine how halachic authorities in France and Germany adhered to the ancient approach and where they extended or innovated the scribal rules in terms of ritually sanctifying writable skins for their holy purpose (lishmah). Finally, I will sketch two elements of Christian religious life and discuss possible impacts for Jewish scribal culture: first, the symbolical identification of parchment as Corpus Christi; second, the presence of Christian practice of consecration in the public sphere.

\section{The Rabbinic Ideal}

Already in rabbinic literature there is a clear conception as to what kinds of skins should be reserved for writing a sefer Torah, tefillin, and mezuzot, and which skins should be used within the profane realm only. Not suitable for the sacral use are mazzah, hippa, and diphtera, skins that were processed less laboriously or not at all. Mazzah is an unprocessed rawhide, which "is neither salted nor treated with flour or gall-nut," "hippa is a skin that is salted but not treated with flour and gull-nut," whereas diphtera "has been dressed with salt and flour but not treated with gall-nut."3 Papyrus, which was the common writing material in the Hellenistic world, was also excluded from the realm of holy scrolls - probably because of its lower durability and its cultural origin. ${ }^{4}$ The Rabbis rather recommended the well-known writing material leather and distinguished between gewil, qelaf and duchsustos. These skins, which have to stem from a kosher animal, passed through all three steps of the ancient process of preparing a writable skin as introduced in the Talmud:

First: salting the skin, which has to be cleaned from the upper hair- and the lower fat-layer in order to stop the organic decay and conserve the material.

Second: flouring the skin in order to withdraw redundant liquid and to soften the surface for a more pleasant writing.

3 bT Shab 79a; Giț 22a; Meg $19 a$.

4 bT Meg 2.2; jT Meg 1.71d. 
And third: tanning the skin with substances like gall-nut in order to strengthen the material.

Gewil, however, in contrast to qelaf and duchsustos, was not processed any further, and thus must have been relatively thick and less flexible. In rabbinic literature, in most cases gewil appears to be related to Torah scrolls, so that scholars like Ludwig Blau or later Menahem Haran assume that this skin was particularly used for writing the biblical scrolls in ancient times. ${ }^{5}$ The Rabbis, however, kept silent about the differences between qelaf and duchsustos and the details of their making. Only later rabbinic authorities give us a clear picture. Thus, Maimonides like all his commentators drew on the interpretation of Hai Gaon when he explained that:

after the hair was removed, the hide was split through its thickness into two, as the leatherworkers know how to do, so that it became two pieces of leather, one thin, on the hair side, and a thicker one on the flesh side, and if these were worked first with salt, then with flour and then with gallnut or other similar substances. Then the hair side was called $d u k h-$ sustus [and recommended for writing tefillin] and the flesh side qelaf [and suitable for writing mezuzot]. ${ }^{6}$

European parchment, however, was prepared with a lime-solution instead of tannins, and was not split but rather stretched within a wood frame, dried and scraped from both sides to the desired thickness. It does not match the rabbinic perception of a kosher writable skin, but nevertheless European Jews adopted it ${ }^{7}$ - first of all because they were almost completely dependent on Christian tanners.

5 Blau, Studien zum althebräischen Buchwesen, 25; Haran, "Bible Scrolls in Eastern and Western Communities," 40, n. 35 .

6 Moshe ben Maimon, Mishneh Torah. Ahavah, III:7-9, trans. Menachem Kellner, The Code of Maimonides. Book Two. The Book of Love (New Haven: Yale University Press, 2004), 74.

7 Thus rabbinic authorities from France such as Jacob b. Meir Tam — better known as Rabbenu Tam-or his disciple Rabbi Eliezer b. Samuel of Metz whose influence extended beyond the borders to the German Jews, agree that "the lime which we put in our qelafim is as acceptable as tannin." Simḥa b. Samuel of Vitry with a similar pragmatism noted in his famous Maḩzor Vitry §517: "It seems to me that if the skin is prepared according to a proper method such as ours, which is better than salting and flouring and tanning, it is lawful and does not require tanning. But (skins prepared) by salting and flouring require tanning, since salting and flouring are not as potent as our lime and soaking in water." There are many other documents, which show that the process of making writable skins for the sacral use according to the 
However, I do not agree with Haran who asserts that for this reason, it was "an easy adoption"8 without hesitation. Rather, the dependency on Christian parchment makers evoked an atmosphere of mistrustfulness and suspicion. It had to be ensured that the skins originated from kosher animals and-even more important - that they were not destined for writing "books of idolatry" on them. To be excluded from the manufacturing process here means the loss of control in a realm that is of existential importance. The mitșvah of wearing tefillin, for example, cannot be fulfilled if the parchment inside the batim is not kosher-even if the one who wears it does not know about the flaw. This holds true all the more with respect to reading the Torah. But how could European Jewry ensure the rabbinic requirement of a kosher writable skin under these circumstances?

Interestingly, none of the sources of medieval Europe use the term "pergamentum," "membrane," or the old-German "perment" but rather "qelafim shelanu," "our qelafim," even though it actually was parchment. This implies a difference between qelaf and parchment_-but on a different, metaphysical level. The manifold scribal literature of medieval Europe gives enough reason for the assumption that this level was reached by the ritual consecration or sanctification of the skins for their holy purpose, by which a hide was transformed from the Christian parchment into the Jewish gewil, qelaf or duchsustos. The new state to which the skins are elevated is permanent and, in contrast to blessings, cannot be repeated. Thus, the terms "consecration" or "dedication" could be used to describe the phenomenon.

In scribal literature, the term 'ibbud lishmah is used for the process of ritual consecration. In order to understand the idea behind this technical term in

Talmudic threefold framework of salting, flouring and tanning was not considered as being necessary. Cf. Barukh ben Isaac of Worms, Sefer ha-Terumah, sect. 190; Abraham ben Nathan ha-Yarhi, Sefer ha-Manhig, sect. 6o; Isaac ben Moses of Vienna, Or Zaru'a, sect. 535; Rabbenu Jacob Tam, "Hilkhot [Tiqqun] Sefer Torah," in: Ginzei Yerushalayim: Kovetz Divre Torah ve-Hokhmah Melitzah va-Shir, ve-Korot ha-Yehudim be-Yeme Kedem, ed. Simon Aaron Wertheimer (Jerusalem: published by author, 1896), vol. 1, 95; Meir ha-Kohen of Rothenburg, Hagahot Maimoniot, Hilkhot Tefillin, we-Mezuzah, we-Sefer Torah, I:9; Jeroham ben Meshullam, Sefer Toledot Adam we-Hawwah, 19d; Isaac ben Abba Mari, Sefer ha-Itur, Hilkhot Tefillin I:55; Jacob ben Asher, Arba'a Turim, Yoreh Deah, Hilkhot Sefer Tora, sect. 271.

8 Haran, "Bible Scrolls in Eastern and Western Communities," 60. 
the context of writing, it is worthwhile to scrutinize its usage in early rabbinic literature. Here, to do or process something lishmah is basically related to four themes: to the concept of Torah lishmah, to the correct issue of a ketubah (marriage document) and a get (divorce document), to the ritual sacrifice within and outside the Temple, and to the manufacturing of the STaM.

The most common usage of this term can be observed in the spiritual surrounding of studying Torah and fulfilling the commandments. The Holy Scriptures should be studied lishmah in the same way as the commandments should be performed lishmah, meaning "for their own sake."9 The truly pious believer concentrates entirely on the Torah and avoids inattentive religious performances of duty. Rabbi Nahman b. Isaac even considers "a transgression performed with good intention [...] better than a precept performed with evil intention"10 which was relativised by the suggestion of the Rabbis to substitute "transgression" with "precept." However, it is consensus that "a man should always occupy himself with the Torah and [its] precepts, even though it be for some ulterior motive, for the result will be that he will eventually do them without ulterior motive."11 The thoughts of the pious man should be fully occupied with holy matters and not be impaired by profane issues. Due to this ideal, with respect to the scribes of the STaM the halachic authorities recommended not to reward them with a high wage for their work, because:

they should not become wealthy for if they became wealthy they would not write. Our Rabbis taught: Those who write Scrolls, tefillin, and mezuzot, they, their traders and their traders' traders, and all who engage [in trade] in sacred commodities [במלאכת שמים], which includes the sellers of blue wool, never see a sign of blessing. But if they engage [therein] for its own sake [לשמה], they do see [a sign of blessing].12

At first sight this conception of holy action does not correspond to the ritual consecration of an object. However, the basic idea appears to be the same: something —in this case a human being — is removed from the world of profane and thus is committed to divinity. It is not surprising that a Sofer STaM is considered to count among those who are obligated to act lishmah, since as a copyist of the sacred Scripture he is moving in the realm of highly divine presence and thus should adjust to this level of holiness to some degree.

\footnotetext{
9 Cf. bT Ber 17a, Sanh 99a u. 105b, Hor 10b, Suk 49b, Pirqe de Rabbi Eliezer 13, jT Ḥag 1:1.

$10 \quad$ bT Naz 23b גדולה עבירה לשמה ממצוה שלא לשמה שמן לשמן

11 bT Naz 23b לעולם יעסוק אדם בתורה ובמצות אפי‘ שלא לשמן שמתוך שלא לשמן בא לשמה לשמה משלה לשמה.

12 bT Pes 5 ob.
} 
The term lishmah is also a fixed technical term in the rabbinic discussion on the documental confirmation of marriage and divorce, since the appropriate document should be issued lishmah, namely in the name of the women concerned..$^{13}$ This holds true in particular for writing a get (divorce act), which has to be presented by the husband to his wife. The procedure is explained in detail within rabbinic literature and certainly reflects the ancient understanding of law with respect to valid documents in terms of purchase agreements, debentures or in the case of releasing a slave. Thus, the clear guidelines for writing the name of a specific woman in a get first of all served to prevent forgery, mistaken identity, and different forms of fraud.

The third context, in which the term lishmah is of an essential meaning, relates to the sacrifice inside and outside the Temple. The dedication of an animal or a food offering was regulated by its dedication to a specific kind of sacrifice. Already during slaughtering, a sacrificial animal should be verbally dedicated lishmah to its ritual purpose, for instance to a Pesach sacrifice, a burnt offering, a guilt offering, a peace offering, or a thank offering. These sacrifices distinguish themselves by their grade of holiness, and the Rabbis developed a complex system of gradation, which assigns both the sacrifice as a whole and each single step of a sacrificing ritual to a certain realm of holiness. The complicated and partly contradictory conception rests upon the assumption that something of lesser holiness cannot be transferred into something of higher holiness-although the opposite is possible. For instance, an animal slaughtered for the purpose of [לשמה] a peace offering, does not correspond to the grade of holiness of a burnt offering. Conversely, if an animal was slaughtered for the purpose of [לשמה] a guilt offering, it can be used for a peace offering or thank offering, and-if it is slaughtered on the 14th of Nisan-even for the Pesach offering. ${ }^{14}$

With respect to the differentiation of food offerings, which make use of vegetable substances such as flour, oil, bread or incense, the Rabbis were less strict regarding the question of correct consecration because "meal offerings are unlike [animal] offerings." ${ }^{15}$ Only the procedure of sacrificing animals is subject to further differentiation in terms of various operations such as slaughtering, receiving the blood, carrying the sacrifice to the altar, sprinkling the blood. ${ }^{16}$ All these actions should be performed with the clear intention in

\footnotetext{
13 Cf. bT Qid 9 and bT Ket 102b.

14 bT Zeb 2.

15 bT Men $2 b$.

16 Mishnah Zeb 1:4. Cf. bT Pes 59b; bT Zeb 3, 4, 7, 10, 11, 13, 36b, 84a, 103b and 114; bT Men 2, $47 \mathrm{~b}$ and 48 ; Pes 59b, 6o, 62b and 63 .
} 
mind to offer a certain sacrifice lishmah since the different realms of holiness should not intersect. ${ }^{17}$

In the context of manufacturing the holy scrolls, the term lishmah is only used in a few cases. Most of these cases are embedded in a general discussion of hazmanah milta hi, lit. hazmanah is a thing. Hazmanah means "to designate" or "to set aside," and the basic question here is "whether an object that acquires a certain status in law when used for a particular purpose acquires that status even when it has only been designated for that purpose."18 The Talmud (esp. Sanh $47 \mathrm{~b}-48 \mathrm{~b}$ ) presents different arguments for and against the notion that mere designation is effective even though the object in question was used for something else before or even after its designation. Could a grave, for example, that was dug for a specific person be used for another corpse? Does an animal that was set aside for a sacrifice "become forbidden until it has actually been used for the purpose"? 19

In the particular case of manufacturing the STaM and associated objects, the opinions of the Rabbanan are divided. Rabban Simeon b. Gamaliel, on the one hand, argues in favor of hazmanah milta in stating that a skin-regardless of whether intended for writing or covering the holy scrolls - that was not addressed for that purpose is not permitted for use even though it stemmed from a clean animal:

A case arose of a heathen in Sidon who used to write scrolls of the Law, and Rabban Simeon b. Gamaliel permitted them to be bought from him. Seeing that Rabban Simeon b. Gamaliel requires the tanning of the parchment to have been for the specific purpose [לשמן עיבוד], will he not require the writing to have been for the specific purpose [לשמן כתיבה]? For it has been taught: If a man overlays the phylacteries with gold or covers them with the skin of an unclean animal, they are disqualified; [if with] the skin of a clean animal, they are fit for use, even though he did not tan it for the specific purpose [לא עיבדן לשמן]. Rabban Simeon b. Gamaliel says: Even if covered with the skin of a clean animal they are disqualified unless it has been tanned for the specific purpose לשמן] עד שעיבדז]! (bT Git 45b, cf. bT Men 42b, bT Sanh 48b)

\footnotetext{
17 Cf. bT Jab 104b; bT Zeb 3, 11a, 36b, 84a and 103a; bT Men 26, 47a, 48 and 78b; bT Pes 60 and 62 .

18 Luis Jacobs, The Talmudic Argument (Cambridge: Cambridge University Press 1984), 122.

19 Ibid., 123 .
} 
On the other hand, one can find the position that a sheath for a Torah scroll and a receptacle for tefillin are permitted for profane purposes until they have been used for their holy purpose. ${ }^{20}$ Thus, a hazmana in this case is considered ineffective and, consequently, is deemed not necessary:

Come and hear! 'If one says to a craftsman, make me a sheath for a scroll [of the law], or a receptacle for Tefillin,' before they are actually used for their sacred purposes, they may be employed for secular requirements; but once used for their sacred purposes they may not be put to secular use!'21 (bT Sanh 48b).

In another context, the designation of a skin for writing a scroll of Law is considered as necessary:

A certain man came before R. Abbahu saying, I have written a scroll of the Law for so-and-so but did not prepare the parchments [גוילין] for the purpose [לא עיבדתים לשמן]. He asked him: Who has the scroll? He replied: The purchaser. He said to him: Since your word is good to deprive you of your fee, it is also good to spoil the scroll (bT Git 54 b).

A scribe, who is not able to ensure that the skins are processed lishmah, should not only refrain from charging a fee but is obligated to withdraw the scrolls in question from ritual usage.

In addition to the material of and around the holy scrolls, the proper consecration of the names of God is a subject of discussion. Every single divine name should be written by the Sofer STaM lishmah "because a scroll in which the names of God have not been written with proper intention [לשמן] is not worth anything"22 and the scribe should not earn any money with it. The objection that a scribe afterwards could "go over [these names] with a pen and so sanctify them [ליעבר עלייהו קולמוס וליקדשיה]," was rejected by the authorities

20 For a more comprehensive explanation, cf. Luis Jacobs, The Talmudic Argument (Cambridge: Cambridge University Press, 1984), 122-132.

21 Cf. also bT Sanh 48a: "If a cloth was assigned for wrapping Tefillin therein, and was so used, one may not tie up coins in it. If it was assigned, but not used so, or vice versa, one may tie up coins in it. But on Abaya's view, viz., that [mere] designation is a material act; if one had assigned the cloth [for the purpose of wrapping up his Tefillin], even though he did not do so, or if he wrapped them in it, and also assigned it [for that purpose], it is so [i.e. the prohibition holds good]; but if he had not assigned it, it is not [forbidden]." bT Git 54 b. 
with the comment that "such a name was not proper."23 In the passage of the Talmud just quoted the verb qiddesh - sanctifying —is used, and thus once again makes clear the intrinsic connection of the idea behind the term lishmah and sanctifying an object.

There are no further examples in the Mishnah and the Talmud where the term lishmah is used with reference to scribal issues. In neither one of the two minor tractates, the Massekhet Sefer Torah and the Massekhet Soferim, is the ritual consecration of either the material or the divine names mentioned. These texts attach great importance to the category of purity, but the idea of a ritual dedication is not carried on here.

To sum up: in the rabbinic literature of antiquity, the term lishmah and the intention behind it-except for its usage in the context of marriage and divorce-marks a border between the profane and the holy realm or between different states of holiness. Cult objects such as a sacrifice, the zizit of a tallit, and the holy scrolls as well as the human being are by focused study part of a complex atlas of holiness, the magical center of which was the Holy of Holies of the Jerusalem Temple. To do or process something lishmah is nothing but the execution of this transition. However, with respect to scribal issues, we do not obtain a clear perception of whether, under which circumstances and how a skin or a related object should be prepared for its ritual use. At least in early rabbinic literature, the conception of ibbud lishmah appears as unformed and as yet inconsistent. Later on in the Arabic-Islamic cultural area ${ }^{24}$ as well as northern Spain, ${ }^{25}$ the concept of 'ibbud lishmah was not a central subject of discussion. None of these sources refers to the ritual component of such a consecration. Only in medieval Christian Europe did the process of sanctifying in the context of manufacturing the STaM become a prescribed, recognizable performance, which was divided into predefined sequences on which a participant drew during a rite. For different reasons now to be discussed, the

23 Ibid.

24 Cf. Luis Ginzberg, "Pirqoi b. Baboi," in Ginzei Schechter (Geniza Studies in Memory of Solomon Schechter), eds. Luis Ginzberg and Israel Davidson (New York: Jewish Theological Seminary of America, 1928), vol. 3, 561-562; Teshuvot Rav Natronai Ga'on, § 8, 264 and 265; Teshuvot ha-Geonim, § 63, 432; Moshe ben Maimon, Mishneh Torah, Hilkhot Tefillin, Mezuzah, Sefer Torah, 1:11, 1:14, 3:15 and 3:17; Moshe ben Maimon, Mishneh Tora, Hilkhot Tefillah u-Virkat Kohanim, 4: 15, 16.

25 Cf. Yom Tov ben Abraham of Sevilla (d. 1320) and Solomon ben Aderet (d. 1310) in their commentaries to bT Git 54b; Yom Tov ben Abraham of Sevilla ad bT Mak 11a, Suk 9a and bT Erub 12b; Nissim ben Reuven of Gerona (d. 1376) ad bT Git 45b, Sanh 48b and Meg 24b to mention but a few examples. 
sacralisation of almost all parts of manufacturing the STaM emerged as a crucial issue of scribal literature.

Scribal literature in medieval Europe lays great emphasis on the performative aspect of consecration, which in earlier sources was not accorded much attention. It would exceed the scope of this article to give a complete picture of all the discussions and multiple opinions of the different halachic schools and rabbinic figures in medieval Ashkenaz and France regarding this subject. ${ }^{26}$ It is even difficult to distinguish between the various intellectual centers since there are so many mutual references as well as contentual and methodological correspondences beyond regional and cultural borders. Nevertheless, it can be observed that the early French Tosafot with respect to practising the lishmah in the context of manufacturing the STaM argue on a highly theoretical level that provides scant insight into performative aspects. Thus, the influential Rabbenu Jacob Tam (d. 1171) of northern France dwells on that subject with a general view on the state of objects designated for a certain purpose without as yet being in use. Like Rashi (ad Git 45b), Rabbenu Tam's argumentation proceeds from the above-mentioned Talmudic discussion (bT Git 45b) on the necessity of sanctifying the parchment and the act of writing for the purpose of its subsequent ritual use and on the related fundamental issue whether a "designation is a thing" [הזמנה מילתא] causing a change of the object with a permanent effect, thus entailing legal consequences. Rabbenu Tam challenges the opinion of Rashi who considered such a hazmanah - like blessings or benedictions - of being without consequences and therefore regarded the ritual designation of a skin lishmah as not absolutely necessary. On the basis of an extensive analysis of various rabbinic arguments from the Talmud and later halachic authorities concerning this question, Rabbenu Tam came to the conclusion that an ibbud lishmah actually is of permanent effect for the material and

26 Concerning the rabbinic culture in France and Germany, see Ephraim Kanarfogel, "Peering through the Lattices." Mystical, Magical, and Pietistic Dimensions in the Tosafist Period (Detroit: Wayne State University Press, 200o); Ephraim Kanarfogel, The Intellectual History and Rabbinic Culture of Medieval Ashkenaz (Detroit: Wayne State University Press, 2012); Talya Fishman, Becoming the People of the Talmud. Oral Torah as Written Tradition in Medieval Jewish Cultures (Philadelphia, PA: University of Pennsylvania Press, 2011); Israel Moses Ta Shma, Halakhah, Minhag u-Meșiut be-Ashkenaz, 1000-1350 (Jerusalem: Magnes Press, 1996). 
necessary with respect to both the preparation of a writable skin as well as the writing itself. In addition, he repeated the recommendation of the Geonim that a Jew should assist if a non-Jew manufactures writable skins, verbalizing a formula by which the material was sanctified for its holy purpose. Writing the holy text and the divine names likewise has to be done lishmah "for the purpose of the Torah of Israel."27

The discourse of Rabbenu Tam on that subject, which was incorporated into and widely distributed by the influential Mahzor Vitry, ${ }^{28}$ received great attention by other halachic authorities in France and Germany, such as Barukh ben Isaac of Worms ${ }^{29}$ (d. 1212), Mordekhai, ${ }^{30}$ Asher ben Yehi'el (d. 1327), ${ }^{31}$ Moses of Sinsheim, ${ }^{32}$ and Isaak ben Moses of Vienna in his Or Zaru' $a^{33}$ - to name but a few. Most of these authors exceeded the tight theoretical halachic frame set by Rabbenu Tam and his narrow circle. Thus, the student of the famous French Tosafist Isaac of Dampierre, Barukh ben Isaac of Worms in his Sefer Terumah proclaimed a more practice-oriented approach in describing a kind of "choreography" of the ritual act of consecration. In accordance with Rabbenu Tam (and in opposition to Rashi), he argues in favor of a ritual which should be obligatory in the course of blackening the houses and the stripes of Tefillin, of manufacturing the skins for the STaM, of writing the holy texts and of copying the names of God. In the course of different working processes, the formula spoken aloud emerges in the Sefer Terumah as the crucial element of the performance. ${ }^{34}$ Thus, with regard to copying the holy text, Barukh ben Isaac of Worms emphasizes that due to the holiness of these objects it was necessary

that one explicitly says: 'I am writing for the purpose of Israel and its holiness'. And if so, the one who explicitly says [the formula] does not have to say [it] for every single letter but at the beginning [of the work only]

\footnotetext{
27 Rabbenu Jacob Tam, Hilkhot [Tiqqun] Sefer Torah, 92-94.

28 Simhah ben Samuel of Vitry, Mahzor Vitry § 517.

29 Barukh ben Isaac of Worms, Sefer Terumah, sec. 190 and 192-197.

$30 \quad$ Mordekhai ben Hillel, Halakhot Qetanot (Menahot), Hatekhelet, sec. 958.

31 Asher ben Yehi'el, Halakhot Qetanot (Menahot), Hikhot Sefer Torah, sec. 9.

32 Moses of Sinsheim, Barukh she-amar, Tikkun Tefillin.

33 Isaak ben Moses of Vienna in his Or Zaru'a, Hilkhot Tefillin, sec. 533, 534, 435.

34 Cf. Caroline Humphrey and James Laidlaw, "Die rituelle Einstellung," in Ritualtheorien. Ein einführendes Handbuch, eds. Andréa Belliger and David J. Krieger (Wiesbaden: vs, Verlag für Sozialwissenschaften, 2008), 135-155; Roy A. Rappaport, "Ritual und performative Sprache," in Ritualtheorien. Ein einführendes Handbuch, 189-208; John L. Austin, How to Do Things with Words (Oxford: Oxford University Press, 1962).
} 
[...] and it is not enough to do it in thoughts but rather it has to be spoken aloud. .35

Similarly, Abraham ben Isaac of Narbonne (d. 1179), who was a mediator between the dialectical method of the early Tosafists of northern France and the more scientific approach of the Spanish rabbis, as early as in the twelfth century noted that "when a Sofer begins to write he says: 'See, I write for the purpose of the holiness of the Torah of Israel." 36 The names of God, he continues, should be consecrated by the scribe "before his feather touches the parchment." With respect to writable skins the great Talmud scholar particularly discusses their retrospective consecration. ${ }^{37}$ He concludes that a nonconsecrated skin can be clamped back onto the frame, where it should be powdered with lime during the verbalization of the formula. ${ }^{38}$ Menahem ben Solomon Meiri (d.1316), who also lived in Provence, described the procedure of consecrating the skins more precisely. He emphasized that "even though a Jew assisted while soaking the skins in the lime solution or in the moment when the skin is turned, there is no truthfulness." Rather, a Jew

has to say a formula in the moment the skin is put into the lime, [namely] that he puts the skins for the purpose of a Sefer Torah or for the purpose of Tefillin or generally for the purpose of the holiness of a script into the vessel in which it is soaked. And this has not to happen in thought only. [...] Concerning writing, too, the scribe should say at the beginning of the process that he writes leshem. With respect to the names of God, also, he should concentrate himself on the uniqueness of the One. [...] Usually at the beginning of writing [the scribe] says that he intends to write a Torah scroll for the purpose of the Torah of Israel and the names of God for the purpose of the Holiness of the ineffable name. ${ }^{39}$

The Provençal Rabbi Aaron ben Jacob ha-Kohen (13th-14th cent.) similarly describes the ritual consecration in his opus magnum Orhot Hayyim. At the beginning of making writable skins, a formula should "pass [a Jew's] lips," such

35 Barukh ben Isaac of Worms, Sefer ha-Terumah, Hilkhot Sefer Torah, sec. 192.

36 Abraham ben Isaac of Narbonne, Sefer ha-Eshkol, Hilkhot Sefer Torah, sec. 13.

37 Cf. Hai Gaon, Teshuvot ha-Geonim, sec. 432.

38 Abraham ben Isaac of Narbonne, Sefer ha-'Eshkol, Hilkhot Sefer Torah, sec. 11.

39 צenahem ha-Meiri, Qiryat Sefer, 1:2; Cf. Moses of Coucy, Sefer Mișwot Gadol, sec. 25: שריך שיאמר בפירוש בתחלת הכתיבה. 
as a scribe before starting his work should consecrate the holy scrolls as well as the divine names right before writing them down "through his mouth."

Similarly Asher ben Jehiel Ashkenazi (13th-14th cent.) who lived and worked in Germany and northern Spain, stated that "at the beginning of writing a Sefer Torah [one should speak aloud]: 'I write this Sefer Torah for the purpose of [lishmah] the holiness of the Torah of Moses."'41 The Talmudic scholar further emphasized that a verbal declaration before writing the holy scrolls is absolutely necessary. Regarding God's name, however, he considered it sufficient to speak in thoughts while copying it "with the dedicated purpose of the holiness of the name" [צריך שיחשוב לשם קדושת השם]. Asher ben Jehiel assured that although the entire procedure of writing a scroll has to be processed lishmah, the writing of the holy name of God stands on a higher level of scribal art, and a scroll made without sanctifying the divine name is of no worth. ${ }^{42}$

In Germany Eliezer ben Samuel of Metz (d. ca. 1198) as well as Rabbi Isaac Or Zaru'a comment upon that subject in close dependence on the Talmud and with manifold references to the early tosafot, give only very limited insight into the "real" ritual practice in their religious environment. ${ }^{43}$ However, subsequent German Talmud scholars such as the famous Rabbi Meir b. Barukh of Rothenburg (MaHaRaM, d. 1293) as well as his students Rabbi Meir ha-Kohen of Rothenburg, Rabbi Mordekhai ben Hillel (d. 1298), and Abraham ben Moses of Sinsheim reveal much more practical and, thus, historical detail, especially in terms of Jewish-Christian relations and tensions with regard to manufacturing the holy scrolls. Furthermore, the ritual character of the consecration became a more and more elaborated conception.

Meir ha-Kohen of Rothenburg summarizes the arguments of his predecessors, emphasizing that if a non-Jew [כותי] does the work of preparing writable skins, a Jew should assist him dedicating the material "for the purpose of holiness" with a verbalization spoken aloud at the beginning of the process. Mordekhai ben Hillel ha-Kohen (d. 1298) also argues in favor of verbalizing a formula, the effect of which depended on the proper intention of the scribe. A skin which was reserved for a holy scroll should be processed lishmah by a Jew:

\footnotetext{
$40 \quad$ Aaron ben Jacob ha-Kohen, Orhot Hayyim, sec. 24 and 25.

41 Asher ben Jehiel, Halakhot Qetanot, Hilkhot Sefer Torah, sec. 4.

42 Asher ben Jehiel, Halakhot Qețanot, Hilkhot Tefillin, sec. 3.

43 Eliezer ben Samuel of Metz, Sefer Yere'im, sec. 399; Isaak ben Moses from Vienna, Or Zaru'a, sec. 533 and 534. Regarding the characteristics of the different rabbinic schools see Kanarfogel, "Peering through the Lattices;" Kanarfogel, The Intellectual History and Rabbinic Culture of Medieval Ashkenaz.
} 
and it is necessary that he speaks the formula: 'I give [this skin] to processing for the sake of an object of holiness [לשם דבר קדושה] and in this way [should also be proceeded] the zizit. And at the beginning of writing a Sefer Torah, it is necessary to verbalize the formula: 'I write everything for the purpose of the Torah of Israel and in the names of God, for the purpose of the holiness.' [...] And it is not enough to do all this just by thought [ואין די בכל אלו במחשבה]..44

Thus, Mordekhai also assigns the consecration of divine names to the acoustic sphere. ${ }^{45}$

Interestingly, this rabbinic circle around the MaHaRaM explicitly addresses suspicions against Christian parchment makers. Rabbi Meir ha-Kohen of Rothenburg, for instance, with almost the same words as Abraham ben Moses of Sinsheim (see below), adds for consideration that non-Jews could have forged the signs by which a writable skin is marked as kosher. ${ }^{46}$ There are other sources that testify to the deep discomfort Jews had with Christians in the context of making the holy books. One of the earliest witnesses of this phenomenon is the influential treatise Barukh she-amar from the late thirteenth or early fourteenth century, which includes an instruction of the correct making of Tefillin by Abraham ben Moses of Sinsheim and a commentary by his disciple Samson ben Eliezer. It is the first in a series of manuals for scribes

44 Mordehai ben Hillel ha-Kohen, Halakhot Qețanot, (Menakhot) chapter qomez rabbah, sec. 966 .

45 The great emphasis on the formula was adopted by following generations with minor variations. The most influential rabbinic work of modern times, the Shulhan Arukh (1565) by Josef ben Efraim Caro from Toledo, adopts this tendency and incorporates the performative declaration at the beginning of writing the scroll, copying the divine names, and preparing the skins for their ritual purpose. The formulas for processing the skins [אורות אלו אני מעבד לשם], writing the Torah scrolls and tefillin [אני כותב לשם קדושת], and

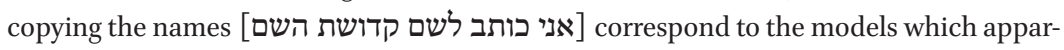
ently emerged at the end of the twelfth or at the beginning of the thirteenth century in France and Germany. Despite minor variants they became part even of modern scribal literature, such as the Sefer Benei Yonah of the Bohemian Talmudist and Sofer STaM Jonah B. Elijah Landsofer (d. 1712), the Sefer Melekhet Shamayim by Isaac Dov Halevi Bamberger (d. 1879), or the Qeset ha-Sofer by Solomon Ganzfried. In the latter treatise, Ganzfried explains why the formula should be verbalized. He wrote: Some say that it is necessary to bring [the formula] over the lips [...], because one cannot impact sanctity by thinking alone [אין הקדושה חלה במחשבה] but by speaking since speaking makes a greater impression [שהדיבור עושה רושם גדולה במשרול].

46 Rabbi Meir ha-Kohen of Rothenburg, Hagahot Maimoniot, Hilkhot Tefillin, we-Mezuzah, we-Sefer Torah, I:11. 
which, on the one hand, includes many arguments of French and German halachic authorities on this subject and which, on the other, corresponds to the scribal practice in Ashkenaz giving a fascinating insight into the day-by-day challenges of a professional Sofer STaM in terms of both ritual and the problematic collaboration of Jewish scribes with Christian tanners. Thus, Abraham ben Moses of Sinsheim describes the procedure of preparing a writable skin for ritual use as follows:

First you should take the skin of a calf to make from it qelafim [...]. Then you should sign them by writing on the inside on top the name of the section in order to distinguish them from those skins on which the sign is made by a needle or by an awl because a non-Jew could have forged it.

Then put the skins in clear water without lime [...] for at least one or two days. [...] In the moment they are laid in clear water say: 'For the purpose of the holiness of the Torah of Israel, for the purpose of Tefillin, Mezuzot and amulets I put these skins into the water'.

After the skins are soaked one or two days in the water, take them out of the water and scrape them with a sharp knife on the flesh- and blood side. Then put them in water with lime. However, before they are put into the lime, shake the lime in a vessel that it became fat and say: "For the purpose of the holiness of the Torah of Israel, for the purpose of Tefillin, Mezuzot and amulets I process these skins'. And it is not enough to speak in thoughts. And also when the skins are put into the clear water should you speak in this manner because all these things are necessary for the making. [...]

Then put the skins into this lime until the hair is drop of from it. If you take them out before the hair is drop off, nobody can write on it because it is diphtera. If it is not fully processed, as it is necessary, it is pasul- not acceptable. Thus it is explained in the gemara that [skins for the sacral use] should be treated with tannins or it is processed with something comparable to it as [we can learn] from the perush of Rabbenu Tam.

$[\ldots]$

And if, after eight or nine days the hair is drop off, take it out of the lime and remove the hair by a sharp knife. Then put it back into the lime but before stir it with a stick and say audibly: 'For the purpose of the holiness of the Tora of Israel, for the purpose of Tefillin, Mezuzot and amulets I process these skins'.

$[\ldots]$

After they were taken out of the second lime solution, if a non-Jew is the one who does the work, should from now on assist a Jew stretching 
the skin that will be qelaf. [...] And when the skin is stretched, take a sharp knife and bring as much water as possible to both sides. Then let the Non-Jew do everything necessary $[\ldots] .{ }^{47}$

To begin with practical issues - apparently, Abraham from Sinsheim considered the possibility that a non-Jew might have forged the mark that designates a parchment as kosher. His disciple Samson ben Eliezer comments upon his teacher's indication in revealing that the desire for financial profit led the nonJew to willful deception. It "would be better," argues Samson, "if the non-Jew could not make profit out of it because for what reason should he forge, which advantage should he then derive from the fraud?"48 He suggests to follow his teacher's advice, namely to make sure that a Jew supervises the process of making kosher parchment. Samson adds for consideration, that "even if the skins are marked with holes in the form of letters by an awl, it is easy for a non-Jew to forge since wherever there are no holes yet he could make holes with an awl in the same manner as a Jew would do."49 Obviously, Jews left signs by means of holes, which indicate whether a skin is produced in a kosher way or whether it is not. There are other sources denouncing Christians for putting patches on defects in the skins in order to mislead their Jewish clientele.

It is remarkable in this context that even Christian sources from this time and area complain about the poor reliability of parchment makers, who-I am citing Nicolaus de Bibera, Carmen occulti auctoris - "are a greedy pack, making no effort but selling in fraudulent intent, and swearing that something was fine what is completely inferior."50 With respect to the parchment makers, several directives are transmitted. An interesting document from thirteenth-century Paris for instance gives evidence of the fact that they were issued to control the business to some degree. The decree Statutum universitatis Parisiensis de pergamenariis was issued charging parchment maker to commit

manifold fraud and dishonesty in buying and selling parchment to the detriment and disadvantage of university and society. [...] For this reason we let them swear, that in purchase and sale they should not do

47 "Barukh she-amar," in Kovez Sifrei STaM, ed. Menahem M. Meshi-Sahav (Jerusalem: Mekhon ha-Talmud ha-yisre'eli ha-shalem, 1970) 13-194, 25-37.

48 "Barukh she-amar," 28.

49 Ibid., 28-29.

$50 \quad$ Nicolaus de Bibera, "Carmen occulti auctoris," in Carmen historicum occulti autoris saec. XIII. Aufgefunden in einer Handschrift der Prager-Universitätsbibliothek. ed. Constantin von Höfler (Vienna: k.k. Hof- und Staatsdruckerei, 1861), 241. 
something wrong but faithfully buy and sell. However, an investigation brought to light, that they break this oath and rather piled up fraud on fraud, malice after malice and so on..$^{51}$

Thus, untrustworthy parchment makers were a nuisance even for Christian scribes. However, for the Sofer STaM it was not simply a question of good quality but also of purity, which depends to some degree on material properties.

On different occasions Jews unavoidably had to establish commercial relations with Christian bookbinders. Several passages from the encyclopedic work Sefer Hasidim reflecting the religious practice of the pious strand of German Jews in the twelfth and thirteenth century give evidence of such cooperation that was excoriated by the Hasidei Ashkenaz. ${ }^{52}$ For instance, an exemplary there is an exemplary Torah binder who rejects the offer of a monk to help him with his work. ${ }^{53}$ From other case examples of the Hasidei Ashkenaz we can deduce that there was a lively exchange of experiences beyond confessional borders. The following paragraph could be interpreted in this way:

[A Jew] went to a monk [גלח] to [teach him] the art of bookbinding. He asked a sage, saying: "The monk told me to bind one of his invalid books [ספר פסול] before his eyes and if he saw that I was not good he would say to me do it so and so.' The sage said to him: 'Do not bind even one section, and do not assist him in binding his books. ${ }^{.54}$

$51 \quad$ "Statutum universitatis Parisiensis de pergamenariis. 30. Oktober 1291," Latin text and German translation in Martin Steinmann, Handschriften im Mittelalter. Eine Quellensammlung, (Basel: Schwabe, 2013), 445-446.

$5^{2}$ In hundreds of passages the Sefer Hasidim deals with all aspects of manufacturing, trading, and handling secular as well as holy books. Several scholars, first of all Malachi Beit Arié, pointed to the fact that "indeed Sefer Hasidim is the richest single medieval source of realistic information on scribal practices anywhere." Malachi Beit-Arié, "Ideal versus Reality: Scribal Prescriptions in Sefer Hasidim and Contemporary Scribal Practices in Franco-German Manuscripts," in Rashi 1040-1990: Hommage á E.E. Urbach, ed. G. SedRajna (Paris: Éd. Du Cerf, 1993), 559-566, esp. 56o; cf. also Collette Sirat (ed.), La conception du livre chez les Pietistes Ashkenazes au moyen age (Geneva: Droz, 1996); Talya Fishman, "The Rhineland Pietists' Sacralization of Oral Torah," The Jewish Quarterly Review 96(1) (2006), 9-16.

53 Cf. the manuscript Parma $3280 \mathrm{H}$ from the Princeton University Sefer Hasidim Database: https://etc.princeton.edu/sefer_hasidim (accessed January 2016), Sefer Hasidim § 680.

54 Sefer Hasidim $\S 681$. 
In the heyday of the scriptorium - when the Sefer Hasidim emerged-JewishChristian cooperation in manufacturing books and in particular a Sefer Torah doubtlessly was more problematic than in later centuries when lay workshops outside the monasteries were established in the surroundings of urban and royal centers of power taking over the flourishing business of making books. Even though there are manifold testimonies of Jewish-Christian oscillations with respect to book making in the Middle Ages, the strict position of the Hasidei Ashkenaz concerning the Torah scrolls encountered broad approval in Jewry for certain reasons. The following narration of the Sefer Hasidim gives a clear impression of what such reasons could be:

Two pious Jews had books that needed binding. There was a monk[גלח] in town who was more proficient than Jewish [bookbinders]. One pious Jew gave his books to the Jewish [bookbinder] to bind who was not as proficient as the monk, because he said: 'How could [the monk] touch a book since there is written: For henceforth there shall no more come into thee the circumcised and the unclean. (Jes. 52,1) All the more so with respect to a holy book [בספר]. When a non-Jew binds he humiliates [מבזה] the books and remnants for possibly he repairs with the remnants his own unclean books.' His companion said: 'Without doubt, [Christians] are not allowed to sew a Torah scroll with sinews; everything that hinders a public reading is not permitted such as writing and binding with sinews [by Christians]. However, they are not forbidden to bind the remaining [profane] books [...], and he insisted that [the Christ] did not use the remnants for his [ecclesiastical] books. ${ }^{55}$

Here the authors of the Sefer Hasidim express an essential consensus among Jewish scribes which did not change over the course of time: there is a gap between profane texts and holy scriptures, which at the same time marks a divide between Jewish and non-Jewish societies. A parchment consecrated for ritual use could be degraded in different ways-first of all by wrong intentions - by Christian clerics and thus make it unsuitable for its holy purpose. "Degrading" here quite literally means the removal of a holy scroll from its sacral to a profane state, thus desecrating it. This holds true even for the margins of the consecrated sheets of parchment that could be cut and superscripted by monks. Conversely, a palimpsest cannot be part of the holy realm. The Sefer Hasidim even considers the writing of an ordinary letter on scraped 
hides from "books of monks [which were] filled with vanities for idolism" 56 as not appropriate. In addition, previous research already pointed to the interesting fact that the Pietists extended the manifold early rabbinic regulations with respect to the holy text scrolls to non-scriptual writings "pointedly stretching the domain of sacred writings so as to encompass inscribed texts of Oral Torah [Mishnah and Talmud]." ${ }^{57}$ The choreography of behavior related to holy books which "make the zone of the sacred visible within the social arena" was also intensified to a remarkable degree. ${ }^{58}$ However, the question of how influential the movement of Hasidei Ashkenaz actually was is still discussed controversially. ${ }^{59}$ Malachi Beit-Arié in his paper on Scribal Prescriptions in Sefer Hasidim came to the conclusion that the hasidic ideal of manufacturing, writing and handling holy books "did not find a receptive audience." ${ }^{60}$ The Sefer Hasidim, nevertheless, provides us with realistic and valuable insights into JewishChristian relations with respect to book art even though its practical guidance probably reflects the radical and reformative approach of an elitist religious group within medieval Judaism.

Considering the term lishmah in its original usage within earlier rabbinical literature and tracing its developments in medieval Europe up to scribal manuals of modern times, a striking change of meaning becomes apparent. Whereas the concept of ritual consecration for a certain realm of holiness was discussed primarily in the context of sacrificial rites in the Second Temple, it was only in medieval Germany and France that legal authorities and scribes established an elaborated concept of ritual sanctification. Crucial ritual elements emerged already within the commentaries by early French Tosafot and Talmudists. However, only from the thirteenth century on is there evidence of clearly defined frameworks of ritual action and of obligatory formulas destined to create a borderline between the holy and profane. In addition, it can be observed that in the course of time processing lishmah included an increasingly broadening spectrum of works. Dyeing lishmah, for example, originally was discussed with respect solely to the zizit of a tallit. Now, however, it was also applied to blackening the Tefillin. Writing the names of God, the letters and taggin was discussed increasingly with regard to ritual consecration, and even the correct intention of a scribe's heart, which was already called for by

\footnotetext{
$56 \quad$ Ibid., $§ 1348$.

57 Fishman, "The Rhineland Pietists' Sacralization," 12.

58 Ibid., 10; Cf. Fishman, Becoming the People of the Talmud, 198-213.

59 Beit-Arié, "Ideal versus Reality: Scribal Prescriptions," 560-561; Ivan G. Marcus, Piety and Society. The Jewish Pietists of Medieval Germany (Leiden: Brill, 1981), 1-10.

6o Beit-Arié, "Ideal versus Reality: Scribal Prescriptions," 566.
} 
Maimonides, became more and more important. Thus, the Jewish community of Germany and France established a far-reaching conception of demarcation, which precluded the holy scrolls and almost all objects related to them from the profane world. Indeed, there remained almost no aspect of writing which was not included in the aura of holiness by a rite of sanctification.

\section{4 \\ The Holy Book in Christian Tradition and the Transfiguration of Its Material}

In scribal literature, the non-Jew appears as a potential factor of impurity endangering purity and holiness of the scrolls by the intentions of an idolater. The routine reference to Maimonides, who emphasized that skins that "were processed by a Gentile are unsuitable, even if [a Jew] had directed him [...] since a Gentile intends his own ends, not those of the person who hires him,"61 reveals the discomfort with materials such as parchment, ink, or other parts of books produced or processed by Christians.

Furthermore, it is not very likely that the Christian conception of preparing, writing and illuminating holy books in the environment of the monastic scriptorium escaped the notice of European Jews. In the present context it can be mentioned only in passing that within monasteries writing a book of hours, prayers, legends of Saints, and first of all a Book of Gospels was more than a simple act of copying. ${ }^{62}$ The exactly identical copying of certain texts does not

61 Moshe ben Maimon, Mishneh Torah, Hilkhot Tefillin, Mezuzah, Sefer Torah, sec. 1:11.

62 Otto Ludwig, Geschichte des Schreibens, Von der Antike bis zum Buchdruck (Berlin: De Gruyter, 2005), vol. 1; Wilhelm Wattenbach, Das Schriftwesen im Mittelalter, 4th ed. (Graz: Akademische Druck- und Verlagsanstalt, 1958); Horst Wenzel, Hören und SehenSchrift und Bild. Kultur und Gedächtnis im Mittelalter (Munich: C.H.Beck, 1995); Martin J. Schubert (ed.), Der Schreiber im Mittelalter (Das Mittelalter: Perspektiven mediävistischer Forschung Vol. 7. 2002, Heft 2) (Berlin: Akademie Verlag, 2003) Here particularly cf.:Jürgen Wolf, "Das ,fürsorgliche' Skriptorium. Überlegungen zur literarhistorischen Relevanz von Produktionsbedingungen," 92-109; and Hildegard Elisabeth Keller, "Kolophon im Herzen. Von beschrifteten Mönchen an den Rändern der Paläographie," 157-182; Anton Legner, "Illustres manus," in Ornamenta Ecclesiae. Kunst und Künstler der Romantik, ed. Anton Legner (Cologne: Stadt Köln, 1995), 187-262; Franz Ronig, "Bemerkungen zur Bibelreform in der Zeit Karls des Großen. Funktion und Ikonologie," in Kunst und Kultur der Karolingerzeit und Papst Leo III in Paderborn, eds. Cristoph Stiegemann and Matthias Wemhoff (Mainz: Verlag Phillip von Zabern in Wissenschaftliche Buchgesellschaft, 1999), 711-717; Jan-Dirk Müller, "Aufführung—Autor-Werk. Zu einigen blinden Stellen gegenwärtiger Diskussion," in Mittelalterliche Literatur und Kunst im Spannungsfeld von Hof 
play such a central role as in writing STaM where the authentic transmission of every single letter has priority. Nevertheless, biblical scriptures, in particular Psalters and the Book of Gospels, are endowed with special features such as lavish illuminations. ${ }^{63}$ The making of these sacral scriptures was considered a godly work. ${ }^{64}$ First of all, the history of salvation both in writing and illuminating was performed with greatest diligence since the Book of Gospels in a way represents the dwelling of God in this world. More than all the other holy books it symbolizes the presence of Christ, who by incarnation of the word appears in this world. Thus, the Book of Gospels iconographically manifests the mutual substitution of book and corpus: Christ appears as book, the book represents the incarnate Christ. ${ }^{65}$ Furthermore, the sanctity of scripture spread to the scribes. Cassiodorus Senator already emphasized that "Satan receives a wound with every word of God copied by the scribe," for he "writes with three fingers expressing the power of the Holy Trinity."66 There are transmitted a number of legends from medieval times which tell wondrous stories about scribes. For example, at the beginning of the thirteenth century, in his Dialogus miraculorum, Caesarius Heisterbacensis reports a certain priest named Richard in the monastery of Arnsberg who

with his own hand wrote countless books; he hoped to be rewarded for his work in heaven. When he died he was buried at a certain place; twenty years later his grave was opened. On this occasion his right hand

und Kloster, eds. Nigel Fenton Palmer and Hans-Joachim Schiewer (Tübingen: De Gruyter, 1999), 149-166; Hagen Keller, “Vom ,heiligen Buch' zur ,Buchführung'. Lebensfunktionen der Schrift im Mittelalter," Frühmittelalterliche Studien 26 (1992): 1-32; Arnold Angenendt, "Libelli bene correcti," in Das Buch als magisches und als Repräsentationsobjekt, Wolfenbütteler Mittelalter-Studien 5, ed. Peter Ganz (Wiesbaden: Otto Harrassowitz 1992), 117-135; Ilona Opelt, "Der antike Autor und sein Buch," in Das Buch in Mittelalter und Renaissance, Studia humaniora 19, ed. Rudolf Hiestand (Düsseldorf: Droste, 1994), 17-31; Joachim Friedrich v. Quack and Daniela Christina Luft (eds.), Erscheinungsformen und Handhabungen Heiliger Schriften, Materiale Textkulturen 5 (Berlin: De Gruyter, 2014).

63 Cf. Christine Jakobi-Mirwald, Das mittelalterliche Buch. Funktion und Ausstattung (Stuttgart: Reclam, 2004), 75-95.

64 Ludwig, Geschichte des Schreibens, 120.

65 Horst Wenzel, "Die Schrift und das Heilige," in Die Verschriftlichung der Welt. Bild, Text und Zahl in der Kultur des Mittelalters und der frühen Neuzeit, eds. Horst Wenzel et al. (Vienna: Kunsthistorisches Museum, 2000), 15-57.

66 Cassiodor, Institutiones divinarum et saecularium litterarum. Einführung in die geistlichen und weltlichen Wissenschaften, ed. Wolfgang Bürsgens (Freiburg: Herder, 2003), vol. 1, 269. 
was found as unchanged and fresh as if it had just been cut off from a living body."67

As becomes evident from this account, it was common within monastic communities to regard writing as a holy act by which the scribe could do penance, asceticism and a kind of praying. ${ }^{68}$ Accordingly, it is not astonishing that even the writing material was charged symbolically, as for example in the book Servasanctus Tuscus de Faenza from the beginning of the fourteenth century:

The blessed Virgin is called 'Book of Life' for she herself is the 'Book of the Generation of Jesus Christ' [...]. First this book was a skin removed from the cow through her conception, purified through her sanctification, stretched through discipline, dried through abstinence, whitened through continence, scraped through poverty, softened through leniency, tenderized through humility, straightened through the salutation of the angel and ruled through his message. ${ }^{69}$

Petrus Berchorius in his Repertorium morale from the fourteenth century compares Jesus Christ with a book written on

virginal parchment $[\ldots]$ that was scraped through flagellation, pricked when he was wounded, laid on the bookrack through crucifixion, illuminated through shedding his blood, bound through his resurrection and disputed through his ascension to heaven. ${ }^{70}$

Similarly, Jacobus de Lausanna in his Compendium moralitatum wrote:

When a parchment-maker scrapes and purges many skins, he should stretch them between woods [...] In this way God father wanted to stretch and bind the mighty Christ on the wood of the cross, so that the weak ones with his help could be purified from the abundance of our sins. ${ }^{71}$

67 Translated from the Latin version printed in Steinmann, Handschriften im Mittelalter, 348.

68 Cf. Ludwig, Geschichte des Schreibens, 121.

69 Translated from the Latin version printed in Steinmann, Handschriften im Mittelalter, 464.

70 Steinmann, Handschriften im Mittelalter, 482.

71 Ibid., 492-492. 
A final example comes from a passage from a monastic sermon from the twelfth century-Sermo super audivi vocem de caelo — which shows how deeply the pious scribe was influenced by this symbolism.

[...] how could we become scribes of God. The parchment on which we are scribing for God is the pure conscience, in which all our good works are noted in everlasting memory making us commendable before God. The knife for scraping is the fear of God, which removes all rough spots of sin and knots of vice from conscience through repentance. The pumice stone for strengthening is the discipline in yearning for heaven, which even removes the smallest aberrance to vain thoughts, so that there is nothing in it resisting the Holy Scripture. The chalk the particles of which are whitening signifies the constant preoccupation with spiritual thoughts which makes the conscience shine. The ruler by which the line is ruled so that the script runs straight is the will of God, to which the ambition of our heart is oriented so that it may be garnished by sincere righteousness.

There is no reason for the assumption that Jewish scribes were unaware of these connotations of the parchment and its production. The close affiliation between scripture and Christ as well as text and corpus was impressively brought to mind to a wide population by means of iconographic and performative presentations. There can be no doubt that no Jewish scribe could have wanted to write on a skin associated with Jesus Christ or the Holy Virgin. There is a multitude of scribal literature from this area which justifies the assumption that the ritual performance of lishmah in such an extensive manner during the working process is not only a cultural peculiarity of European Jewry but rather a reaction to their environmental culture. The concept of sanctification should be considered in the sense of the biblical usage of the Hebrew root $q d s h$ in its meaning as "designated for" and "separated from." ${ }^{2}$ The aspect of separation in terms of holiness (qadosh) was continued by rabbinic authorities of the Middle Ages and keeps resonating in the rabbinic usage of the expression ibbud lishmah.

72 Baruch J. Schwartz, "Israel's Holiness: The Torah Traditions," in Purity and Holiness. The Heritage of Leviticus, eds. Marcel J.H.M. Poorthuis et al. (Leiden: Brill, 200o), 47-6o; concerning the term $q d s h \mathrm{cf}$. notes 2,3 and 4. 
The image, however, of Jewish diasporic existence as a self-contained, secluded minority with atavistic features, which persevered in its identity within a Christian-dominated society by rites of demarcation, appears as too simple. It is remarkable that European scribes and halachists separated their holy scrolls from the "intention of Gentiles" by means of ritual consecration, since a consecratio (consecration of persons) or dedicatio (consecration of realia) played a very important role within Christian Europe in the Middle Ages. ${ }^{73}$ It was even possible to cause a permanent effect with legal consequences by means of a benedictio which had to be performed by an authorized person. Although the original purpose of a benediction lies in the glorification of God without changing the person or the object, the function of a benediction is almost undistinguishable from a ritual consecration at that time. Hence, the quasi-magical impact of a consecration was partly conveyed to blessings, amounting to a downright "inflation of sanctifications." In view of this development, the question appears justified whether this Christian fervor for ritual consecrations and benedictions might have been adopted by Jewish religious practice and whether the defence of the Jewish canon was achieved by means of Christian devices. This hypothesis can be advocated only with a deeper view into the Christian practice of consecrations and benedictions because first of all, the question must be raised as to what extent the Jewish society could have become aware of these rites. Was it possible at all that a non-Christian could gain insight into the Christian practice of consecration? Is its unconscious adaptation by Jewish religious practice conceivable without its refusal as being "Christian?"

In his pivotal study Die kirchlichen Benediktionen im Mittelalter, on the basis of comprehensive source material Adolph Franz noted that "indeed, the entire public and private life of medieval Christianity was accompanied by ecclesial benedictions." 74 Several classic ceremonies of consecration, such as baptism and Eucharist, were celebrated inside the churches, and thus were concealed from the eyes of most Jews. This also holds true for a part of the so-called sacramentals or sacramenta minora such as exorcisms, which were spoken to cast out demons. Clerics preferably treated people being "possessed by demons" within the churches or monasteries near the altar and the stoup where the

73 Lexikon für Theologie und Kirche (Freiburg etc.: Herder, 2004), vol. 10, col. 1004.

74 Adolph Franz, Die kirchlichen Benediktionen im Mittelalter (Freiburg im Breisgau: Herder, 1909), vol. I, 38-39 (reprint Graz: Akademische Druck- und Verlagsanstalt, 1960). 
sufferer occasionally had to endure an ordeal for days. ${ }^{75}$ In addition, the nonChristian society remained excluded from clerical consecrations of sovereigns, knights and their swords, certain consecrations of oil and water, the consecration of pilgrims as well as from many benedictions of private life. ${ }^{76}$

Nevertheless, the two volumes of Franz's study describe a multitude of scenarios which were performed by Christians in the open air, and thus could be watched by Jews as well. For example, these rituals include the benediction of a new house, of fields, fountains, or cattle. People brought the first fruits from the fields or gardens as well as medical herbs to church for benediction; the festive consecration of grapes was a common custom. Even stones attributed with healing powers were subject to benedictions. In case of epidemic diseases, the church was on the scene with benedictions:

[...] when black clouds threatened seed and fruit with spoilage, the priest, surrounded by the frightened community, had to speak one of those weather benedictions, the power of which the weather demons had to yield according to folk belief. Whenever there was a plague of mice or insects, exorcisms were performed in order to expel the vermin. When floods were looming, people trusted in an ecclesial blessing; against a raging firestorm the palla of chalice and other consecrated objects had to help. ${ }^{77}$

There are various reports about Palm Sunday before the Holy Week which give evidence of the dramatic enactment of the appendant processions and their reception by the public. ${ }^{78}$ The ritual also involved processions of sacraments in the course of which a sacramental blessing by a consecrated host was bestowed on several stations of altars. Despite disapproval by some Christian scholars, even in case of fire, storm or epidemic, the monstrance was carried out of the church by clerics reading — for instance for a weather blessing - the beginnings of all four Gospels while performing impressive processions "over hills and valleys" in order "to exorcise the air with the body of Christ." ${ }^{\text {"9 }}$ Such processions were not uncommon, giving the opportunity to all spectators to

75 Adolph Franz, Die kirchlichen Benediktionen im Mittelalter (Freiburg im Breisgau: Herder, 1909), vol. 2, 545-615, esp. 555 .

76 Franz, Die kirchlichen Benediktionen, vol. 1, 39.

77 Ibid.

78 Ibid., $470-507$.

79 Franz, Die kirchlichen Benediktionen, vol. 2, 108. 
experience the deep belief of the Christian society in the power of the verbalized formula.

Furthermore, the consecration of ships and public buildings most probably did not remain hidden from Jewish eyes. It can also be assumed that due to the partly close commercial and private relationships between Jews and Christians in medieval Europe, Jewish neighbors were aware also of the countless benedictions performed in the private domain. The multifarious applications of holy water outside the church convey the impression of a veritable culture of ritual conjuration deeply anchored in folk religion. The flood of consecration formulas was staunched only at the end of the fifteenth century by means of printed rituals. ${ }^{80}$

The question arises as to whether the rites of consecration or dedication could be adopted with respect to the ritual practice of writing the STaM by halachic authorities and the Jewish society without objection. In fact, ritual consecration was and still is a natural part of Jewish religious life as well. In biblical times, priests, kings, warriors, altars, objects of the temple and sacrifices were consecrated [חנך]. Later on, the festive consecration of cemeteries and synagogues as well as other occurrences of communal life prompted rites of consecration. Some of these ancient sanctifications influenced Christian practice and thus cannot be considered as being specifically Christian. This popular form of ritual action in Christian Europe could all the more easily be adopted and used by Jews, even though the impulse came from outside.

Considering the research literature on Jewish rituals in medieval Europe from the last two decades, the development of Jewish scribal law and practice in France and Germany underwent during the twelfth and thirteenth century appears to be only a minor aspect of a more general tendency. In his pivotal study Rituals of Childhood, Ivan Marcus was one of the first to challenge the view of European Jews as a cultural and political minority that was isolated from its Christian neighborhood. He suggested the term "inward acculturation" in order to describe the contrast to modern Jewish acculturation, since Jews in Latin Christianity did not assimilate or convert to Christian culture but "adapted Christian themes and iconography, which they saw all around them every day, and fused them — often in inverted and parodic ways - with ancient Jewish customs and traditions." ${ }^{\prime 1}$ Thus, the increasing effort Jewish

\footnotetext{
8 o Ibid., 641-649.

81 Ivan G. Marcus, Rituals of Childhood. Jewish Acculturation in Medieval Europe (New Haven: Yale University Press, 1996), 12; cf. Israel Yuval, "Vengeance and Damnation, Blood and Defamation: From Jewish Martyrdom to Blood Libel Accusations," Zion $5^{8}$ (1993): 33-90
} 
halachists and scribes made to include almost all parts of manufacturing the holy scrolls into a broad conception of sanctification against the backdrop of contemporary Christian culture can also be interpreted as a response to the Christian environment. The exclusion of Jews from the trade of tanners, the enormous religious and social function that was ascribed to the holy books within Christian society, as well as the tremendous affinity for all kinds of consecrations in Latin Europe are only some aspects of a complex social, religious and political system that could be seen as a trigger of ritual dynamics which changed the Jewish approach to manufacturing the holy scrolls. It seems to be paradox, but demarcation and acculturation in the context of ritual writing the STaM are two sides of the same coin.

Annett Martini, Ph.D. (2010) Freie Universität Berlin, Germany; Research Associate at the Institut für Judaistik Berlin (2005-2016); postdoctoral fellow and head of the project "Die hebräischen Handschriften der Erfurter Sammlung als kulturhistorische Zeugen jüdischen Lebens im Mittelalter" (since October 2017); Habilitation (2018) Freie Universität Berlin, Germany; Publications: Yosef Giqatilla. The Book of Punctuation: Flavius Mithridates' Latin Translation, the Hebrew Text, and an English Version. Edited with Introduction and Notes by Annett Martini (Turin: Nino Aragno, 2010); "Seven Mystical Poems on the Hebrew Vowels as Interpreted by Yosef Giqatilla and Mordekhay Dato," European Journal of Jewish Studies 5(2) (2011): 205-218; "Vom Symbol zum Schweigen: Pseudo-Areopagitas De symbolica theologia

[Hebrew]; Talya Fishman, "The Rhineland Pietists' Sacralisation of Oral Torah," Jewish Quarterly Review 96(1) (2006): 9-16; Talya Fishman, "The Penitential System of Hasidei Ashkenaz and the Problem of Cultural Boundaries," The Journal of Jewish Thought and Philosophy 8 (1999): 201-229, see n. 3; Ze'ev W. Falk, Jewish Matrimonial Law in the Middle Ages (Oxford: Oxford University Press, 1966); Esther Cohen and Elliot Horowitz, "In Search of the Sacred: Jews, Christians and Rituals of Marriage in the Later Middle Ages," Journal of Medieval and Renaissance Studies 20(2) (1990): 225-249; Elisheva Baumgarten, "Circumcision and Baptism: The Development of a Jewish Ritual in Christian Europe," in The Covenant of Circumcision: New Perspectives on an Ancient Jewish Rite, ed. Elizabeth Mark (Lebanon, NH: Brandeis University Press, 2003), 114-27; Elisheva Baumgarten, "A Tale of a Christian Matron and Sabbath Candles: Religious Difference, Material Culture and Gender in Thirteenth Century Germany," Jewish Studies Quarterly 20 (2013): 83-99; Elisheva Baumgarten, Mothers and Children: Jewish Family Life in Medieval Europe (Princeton: Princeton University Press, 2004); Elisheva Baumgarten and Judah D. Galinsky (eds.), Jews and Christians in Thirteen-Century France (New York: Palgrave Macmillan, 2015). 
im Spiegel von Johannes Reuchlins christlicher Kabbala," PaRDeS 19 (2013): 175-190; "The Ritualization of Manufacturing and Handling of Holy Books by the Hasidei Ashkenaz and the Impact of the Monastic Book Culture in the Middle Ages" (forthcoming); "Arbeit des Himmels': Jüdische Konzeptionen des rituellen Schreibens in der europäischen Kultur des Mittelalters. Eine Studie zur Herstellung der STaM in Frankreich und Deutschland unter Berücksichtigung der christlichen Schreibkultur (forthcoming). 